\title{
Cytoplasmic male sterility in sorghum: organization and expression of mitochondrial genes in Indian CMS cytoplasms
}

\author{
ANIRUDDHA P. SANE, PRAVENDRA NATH and \\ PRAFULLACHANDRA V. SANE
}

Figure 1 of this article, on page 154 of this volume (vol. 75, no. 2, August 1996), was inverted because of a printing error. The corrected figure is printed below.

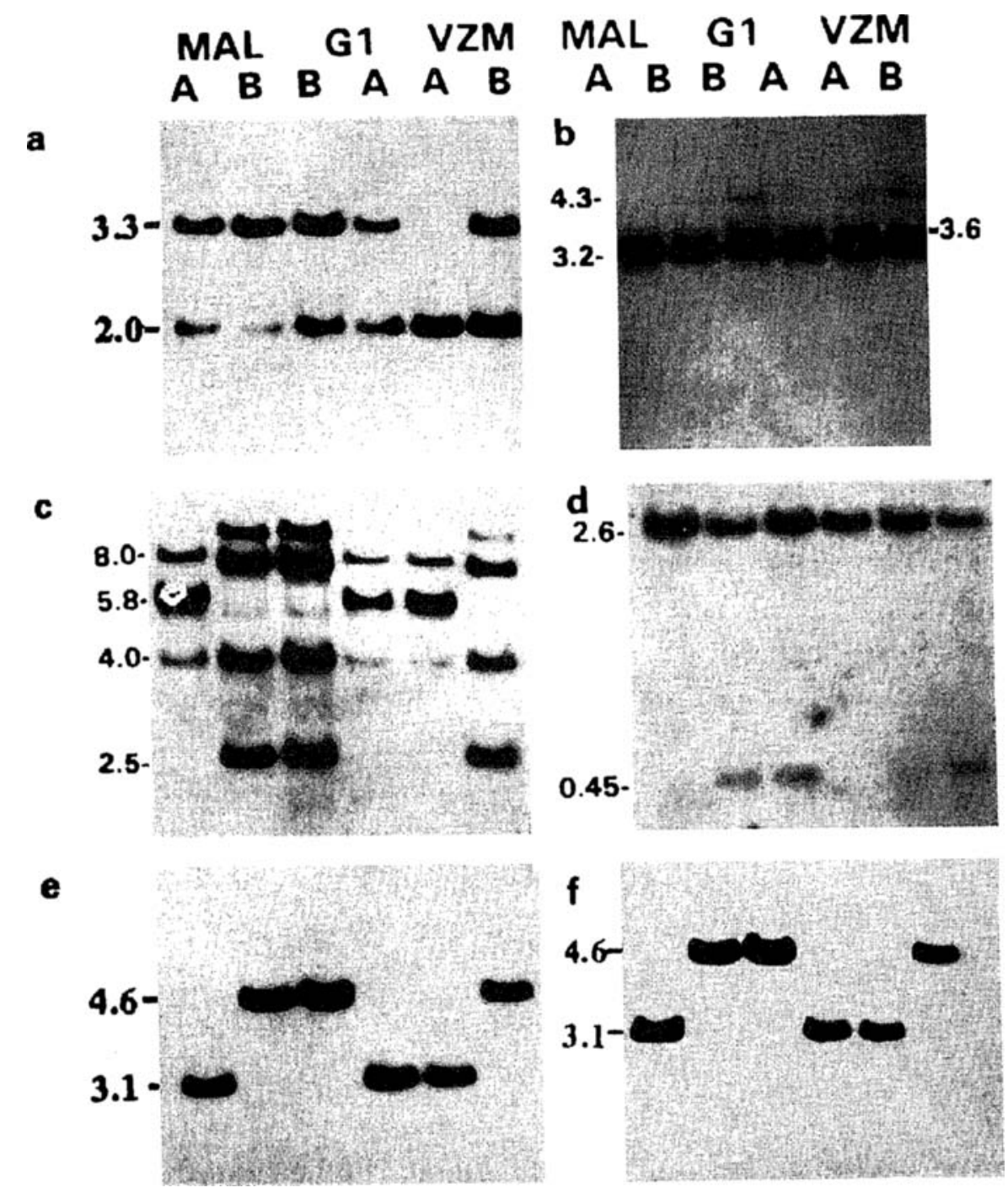

Figure 1. Southern blot hybridization of (a) atp6, (b) atp9, (c) atp $A,(d) \operatorname{rrn} 18,(e)$ nad3, and (f) rps 12 probes to HindlII-digested mitochondrial DNA of various cytoplasms. A, male sterile lines; B, maintainer lines; MAL, Maldandi; G1, Guntur; VZM, Vizianagaram. The numbers on the left of the panels indicate size in $\mathrm{kbp}$. 